\title{
Beyond the novelty effect: EFL learners' attitudes towards ICT use in the classroom
}

\author{
MARTA KOPINSKA*
}

University of the Basque Country UPV/EHU, Faculty of Arts, Paseo de la Universidad 5, Vitoria-Gasteiz, 01006, Spain

\section{THEMATIC ARTICLE}

Published online: March 30, 2020

(C) The Author(s) 2020

\section{ABSTRACT}

The present study explores high school students' (aged 16-17) attitudes towards the use of technology Information and Communication Technology (ICT) in the English as foreign language (EFL) classroom. While digital competence has become one of the core skills in our society, ICT is gaining more presence in the EFL teaching and learning. However, it is not widespread in the mainstream education, as it is the case of Spain, especially at high school level. There is also still some reticence on the part of the teachers to let the ICT be part and parcel of their daily practice. Since adolescents often experience a motivational drop as far as learning a foreign language (FL) in school setting is concerned, EFL teachers should promote the integration of ICT in classroom activities, as research has shown that technology-supported activities may contribute to engaging students in the process of learning a FL and act as a motivating factor. This paper examines 77 EFL learners' responses to a questionnaire administered before and after the implementation of an 18-month ICT-based intervention in their classroom. The main findings reveal that attitudes towards technology were positive and they were maintained beyond the possible "novelty effect", which supports the claims in favor of ICT's integration in EFL teaching.

\section{KEYWORDS}

ICT, CALL, attitudes, EFL teaching

\footnotetext{
*Corresponding author. E-mail: marta.kopinska@ehu.eus
} 


\section{INTRODUCTION}

While the "digital revolution gains momentum" (Delgado, Wardlow, McKnight, \& O’Malley, 2015, p. 410) in our lives and our schools, the research on the integration of technology in the foreign language (FL) classroom and its effects on learning is increasing rapidly. Even though the question whether technology exerts a beneficial influence on students' achievement still remains unclear (Delgado et al., 2015), in general terms, it can be affirmed that Information and Communication Technology (ICT) -which refers to, among others, computers, the Internet, telephones, and digital access to media- does positively affect learners' motivation towards language learning, and their selfperceived improvement (Lasagabaster \& Sierra, 2003). Therefore, there is a need to find ways to support and harness the opportunities offered by technology to the benefit of language learners, as the ICT are here to stay, and being digitally savvy is one of the key competences of school curricula (European Parliament, 2006). Digital competence is defined by Ferrari (2013) as a "confident, critical and creative use of ICT to achieve goals related to work, employability, learning, leisure, inclusion and/or participation in society" (p. 2). The communicative competence nowadays not only subsumes being able to communicate in multiple languages, but also the digital communication.

However, in spite of educational authorities' efforts and funding aimed to equip the classrooms with the necessary infrastructures, the integration of technology in FL classrooms is not yet as widespread as expected. Moreover, most of the digital programs are intended for primary and lower secondary pupils, with high school pupils often lagging behind (e.g., Eskola 2.0). What is more, the existing body of research has been conducted majorly at the tertiary level, with few studies relying on high school adolescents. That is why the present study aims at investigating learners' attitudes towards classroom integration of technology at this particular level of education, as there is currently a dearth of studies aimed at examining what high school students of English as foreign language (EFL) think of using ICT for educational purposes.

\section{EDUCATIONAL USE OF ICT}

In the light of a tendency to a gradual decrease in adolescent learners' motivation towards FL learning found in research, especially in instructional settings (Henry, Sundquist, \& Thorsen, 2019; Williams, Burden, \& Lanvers, 2002), the integration of technology in the FL classes is generally considered a very useful tool to support both the digital and the linguistic competence of our students, since the use of technology in the classroom can certainly add value to the process of learning by engaging the learners in it and motivating them, as noted in some studies in the field (Czékmán, 2018; Golonka, Bowles, Frank, Richardson, \& Freynik, 2014; Ushioda, 2011).

However, Hockly (2013, p. 82) turns the attention towards the ways in which ICT is employed and insists that "it is not the technology itself that enhances teaching or learning, but rather the use to which it is put". As such, the potential of Computer-Assisted Language Learning (CALL) could be explained following Puentedura's (2010) SAMR model, which suggests that technology can be used in learning activities in one of the following ways: Substitution, Augmentation, Modification and/or Redefinition (see also Hockly, 2013). According to this model, technology may solely act as a tool or medium substitute with no functional change (Substitution), a direct substitute with a functional improvement (Augmentation), it may allow for significant task redesign (Modification), or even for the creation of new tasks, which were 
previously inconceivable (Redefinition). Substitution and Augmentation are seen here as an enhancement of teaching and learning, whereas Modification and Redefinition are understood as its transformation. However, the common use given to technologies which can be observed in the classrooms very frequently does not reach beyond a mere substitution of traditional tools, and the ICT are being employed for the sake of using them (Fitzpatrick, 2004; Hockly, 2013; Li, Snow, Jiang, \& Edwards, 2015; Puentedura, 2010).

In their review article on the results reported in research, Hew and Cheung (2013, p. 57) argue that the use of technology does appear to have a "general positive effect", even though at present actual causal effects of ICT on improvement in students' learning achievement cannot be determined with certainty, due to various methodological concerns, among others, to a relatively short span of the studies reviewed. The researchers note that none of the studies they analyzed reported a negative influence on learning, however, the beneficial effects found in the studies "are not necessarily attributed to the technologies per se but to how the technologies are used” (Hew \& Cheung, 2013, p. 58; see also Schmelzer et al., 2016), and how one conceptualizes teaching and learning in order to help students enhance their performance. They put forward that more longitudinal research is required in order to mitigate the "novelty effects" of the ICT use in the classroom (p. 58).

\section{ICT'S PRESENCE IN SCHOOLS AND EFL TEACHING WITH ICT: THE CASE OF SPAIN}

Spain has been taking some steps to follow the recommendations of the European Parliament (2006) and the European framework for the digital competence (DIGCOMP) (Ferrari, 2013), to apply the guidelines concerning the development of digital competence of Spanish pupils and the integration of technologies in the education system to its core curriculum. In fact, the last two educational laws include a broad reference to digital competence. Nevertheless, the effects can be mostly seen in primary and, to a lesser extent, lower secondary education, while high schools have not undergone the necessary transformation yet.

Moreover, the development of pupils' digital competence brings about an adaptation of the traditional education system in the light of the changes introduced by ICT to basic literacy, reading and writing, as well as a new set of knowledge, skills and attitudes necessary to become a competent person in a digital environment (BOE, 29 January 2015, p. 6995). In the Basque Autonomous Community in Spain, the context in which the present study was developed, educational authorities consider ICT literacy an integral part of the key cross-curricular competence of communication, understood as the "verbal, non-verbal, and digital communication competence" (EHAA, 15 January 2016, p. 61). Such key cross-curricular competences permeate the whole curriculum and all school subjects, forming the basis of the acquisition of other competences. These three pillars of communication comprise the ability to use verbal, non-verbal, and digital communication in a complementary way, so as to communicate efficiently and in adequate manner in personal, professional, social, and academic environments (see also EHAA, 23 September 2016, p. 10). In the Basque context, such projects as Eskola 2.0 aim at total digitalization of classrooms, starting from grades 5 and 6 in primary education (1011 -year olds) and grades 1 and 2 in lower secondary (12-13-year olds). Moreover, this particular project, which, up to date equipped the Basque classrooms with about 80,000 computers, 
encompasses also providing teachers with professional training with ICT and the new type of methodology their classroom integration demands, as well as guidance and help throughout the implementation of new resources, and the creation of new multimedia contents and materials. The overarching goal of Eskola 2.0 is a substantial improvement of teaching quality, an adaptation to the globally networked social needs, and the reduction of digital divide, among others. However, similar projects at higher levels of secondary education can hardly be found.

Among other Spanish regions, the Basque Country is at the top of the list when it comes to the number of computers per citizen, computers at home and the use of the Internet (Lasagabaster \& Sierra, 2003, p. 301). Regarding the frequency of the use of technology at school, it is close to the EU mean. However, and despite the fact that the general majority of Spanish pupils attend rather digitally supportive schools, both teachers' and students' confidence in their ICT skills is below the EU mean in most grades, contrary to what might be expected (European Commission, 2012, p. 26).

The presence of ICT in language teaching and learning in European countries was examined in a survey, which gathered the key data on language competences and language teaching (Eurydice, 2012). According to the overall findings, in most of the countries or regions within the 14 countries participating in the survey, ICT were not regularly used during language lessons, as reported by the majority of students, although there was a substantial variation between countries (p. 12). As a matter of fact, on average, the percentage of students (aged 15-16) who claimed they regularly use ICT (i.e., Internet, computer programs or language laboratory) during their language lessons did not reach $20 \%$ (p. 107). Some countries, such as the Netherlands and, to a lesser extent, Sweden, or Slovenia showed higher percentages, at least for two of the three mentioned technologies, as can be observed in Fig. 1 below. Spain's (ES) average was somewhat higher than the EU mean, with slightly above the mean of one in five (20\%) secondary students reporting a regular use of the Internet and computer programs in their language lessons. Nevertheless, much more could be done to raise the frequency of ICT use in FL classrooms, given the potential of such resources in the learning and teaching of a FL.

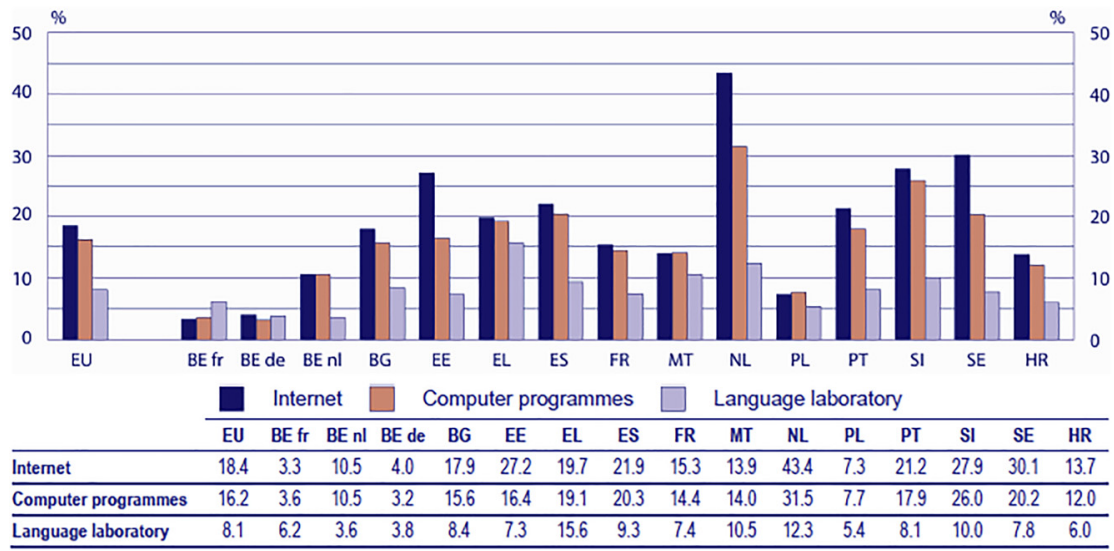

Figure 1. Percentages of students (15-16-year-olds) who say that ICT is regularly used during their language lessons (Eurydice, 2012, p. 107) 
These measurements were made on the secondary level, and thus the situation in high schools is likely to differ from this snapshot, as at this education level the ICT use in EFL classes tends to be rather uncommon.

\section{LEARNERS' ATTITUDES TOWARDS ICT IN THE FL CLASSROOM}

Considering the use of ICT in FL teaching, students' attitudes towards technologies and their use in the classroom are, without any doubt, an important issue, since they can largely influence their (un)willingness to interact with them. Warschauer (1996) puts forward that there is a potential reciprocal relationship between possessing more knowledge and experience with technology and holding a favorable disposition towards it. Moreover, as Stockwell (2013, p. 163) argues, students' positive mindset to use a technology "could very well lead learners to develop motivation to learn a language (...) and, conversely, sustained motivation to learn a language could result in a desire to use technology".

The general "fun factor" usually associated with the use of technology in learning should not be overlooked, as it contributes to pupils' positive learning experience (Martínez-Rico, 2006; Stockwell, 2013). In the already mentioned European survey on ICT in education (European Commission, 2013), an overwhelming majority of students exhibited positive to very positive attitude towards the impact of ICT use on the classroom atmosphere and on the learning process. Regardless of the specific issue or grade concerned (grades 4, 8, and 11), 70-75\% of the students agreed that "using a computer is fun", and that they use them for "learning to help with future adult life" (European Commission, 2013, p. 121). Also, Doiz, Lasagabaster and Sierra (2014) when they asked Basque learners of English from a Content and Language Integrated Learning (CLIL) program what (de)motivated them in class, found that the use of computers for classroom activities resulted one of the most appreciated aspects. As a matter of fact, for those aged 14-15, it turned out to be the 3rd top category of what they liked the most in their classes.

Liu (2009) found overall positive attitudes towards ICT and the integration of technology into English learning among 140 Chinese university students, irrespective of their ICT competence, although the students reported scarce use of ICT in English classrooms on a daily basis, and that their incorporation into the curriculum was far from being the norm. Positive attitudes are considered essential for successful language learning processes and for meaningful use of technologies, as suggested by Guo and Stevens (2011) in their study on use and usefulness of wikis conducted among 205 first year Australian university students. The students appeared not to especially like wikis, however, they showed a more positive attitude towards it if they believed that wikis would be useful for the completion and improvement of their assignment quality.

Even though students are fond of the use of computers for classroom activities (Doiz et al., 2014), and variables related to enjoyment seem to be positively affected by the ICT use (Martínez-Rico, 2006, p. 207), the capability of the "digital natives" (Prensky, 2001) of consciously applying their digital skills to support their language learning has been questioned (Levy, 2009; Margaryan, Littlejohn, \& Vojt, 2011). However, there is some evidence regarding positive attitudes of the learners towards ICT and their educational use (De Moya, Hernández, Hernández, \& Cózar, 2011; Hernández, Hernández, De Moya, García, \& Bravo, 2010; Ipiña, 2012; Siragusa \& Dixon, 2009). The learners acknowledge the advantages of the employment of technologies in language learning (Liu, 2009; Martínez-Rico, 2006), and regard them an 
important and useful tool for searching for information and broadening their knowledge (Hernández et al., 2010). Nevertheless, some researchers claim such results may be accounted for by the "novelty effect" of the ICT and call for more longitudinal studies (Hew \& Cheung, 2013).

Since attitudes, beliefs and behaviors are linked, an integration of ICT in classroom practice is important in the formation of positive learning experiences and favorable attitudes towards educational use of technology in EFL teaching and learning.

\section{RESEARCH QUESTIONS}

The objective of the present study is to take a closer look at the integration of ICT-related educational intervention comprising technology-mediated sessions which would not be considered a simple "add-on" to the project, but become the core of the learning activities (Puentedura, 2010). The present research is part of a larger study (Kopinska, 2016), and it aims to cater for the need of longer studies, as it has been developed throughout one school year and a half. Its novelty stems from its focus on high school EFL learners, as the majority of the research was carried out among university students. The research questions addressed in the present study were the following ones:

1. What are high school EFL learners' attitudes towards the educational use of ICT?

2. In what way are these attitudes affected by the experience of using technologies in their EFL classroom?

\section{METHOD}

\section{Participants and ICT-intervention design}

The participants were 77 EFL learners from a public high school in a major city in the Basque Country in Spain, 48 females and 29 males, aged 16-17, whose general level of English was intermediate (B1-B2, CEFR). Out of three weekly sessions of their usual English language course with the corresponding EFL teacher, the learners had one session of ICT use. The total number of hours of those sessions within the 18 months of the duration of the study was 21: 11 hours the first year (half-an-hour weekly session) and 10 hours the second year $10 \mathrm{~h}$ (1 hour per week).

The intervention consisted of technology-mediated activities, such as the use of the Web for information search and WebQuest-type activities, self-paced audio-visual comprehension tasks, blogs creation and blog posts writing for written performance, as well as the use of the Power Point program as a support for digitally recorded oral presentations. The topics regarded global affairs, closely linked to the types of discourse and topics dealt with in the students' textbook, such as gender equality, fake news, or the spread of the Internet.

\section{Data collection instrument and procedure}

Data was gathered via questionnaire (see Appendix), adapted from Ipiña (2012) and Gray et al., (2009), which aimed to tap into EFL students' attitudes towards the use of ICT in their learning environment. It consisted of six scales: 
1. ICT as a support for learning (items 1,2, 3, 11 and 21; sample item: The use of technologies in my studies will help me get better results in my subject.)

2. ICT as means to improve English (items 5, 7 and 19; sample item: The use of technologies in my studies will help me improve my level of English.)

3. ICT use in the classroom (items $8,10,16,17$ and 20; sample item: The use of technologies in my studies will help to make the class more interesting.)

4. ICT as means to improve skills and career (items 4 and 6; sample item: The use of technologies in my studies will improve my career or employment prospects in the long term.)

5. ICT school access (items 14 and 15; sample item: The quality of the equipment at my school is not very good.)

6. ICT use difficulties (items 9, 12, 13 and 22; sample item: It is difficult to use technologies in English classes.)

In order to assess the potential impact of the use of technologies in the EFL classroom on learners' attitudes towards ICT, the questionnaire was administered at different time points, although in the present report we focus on the results obtained prior to the ICT intervention (pre-test) and 18 months later, after the 21 hours of ICT intervention (post-test) in order to longitudinally measure the impact of the technology-led classroom experience. It was hypothesized that the actual experience with classroom "hands-on" use of ICT would positively influence students' attitudes towards the educational employment of technology, by showing its potential and usefulness for EFL activities.

At the end of the project the participants of the study were also interviewed by means of focus groups (8 groups of 6-10 students) which lasted, on average, 30-40 minutes. They were digitally recorded, transcribed and analyzed in order to gather qualitative insights on their ICTrelated experience.

\section{RESULTS}

Data obtained via questionnaire were coded and analyzed by means of the SPSS 23 program. Paired-samples $t$-tests were performed in order to answer the research questions. Table 1 below

Table 1. Attitudes towards ICT. Main factors and corresponding reliability coefficients, means and standard deviations

\begin{tabular}{|c|c|c|c|c|c|c|c|}
\hline \multirow[b]{2}{*}{ Variables } & \multirow[b]{2}{*}{$\begin{array}{c}N^{\circ} \\
\text { items }\end{array}$} & \multicolumn{3}{|c|}{ Pre-test $(N=77)$} & \multicolumn{3}{|c|}{ Post-test $(N=62)$} \\
\hline & & $\begin{array}{c}\text { Cronbach's } \\
\alpha\end{array}$ & Mean & $S D$ & $\begin{array}{c}\text { Cronbach's } \\
\alpha\end{array}$ & Mean & $S D$ \\
\hline ICT as support for learning & 5 & 0.79 & 3.62 & 0.61 & 0.71 & 3.64 & 0.61 \\
\hline $\begin{array}{l}\text { ICT as means to improve } \\
\text { English }\end{array}$ & 3 & 0.76 & 3.44 & 0.69 & 0.87 & 3.52 & 0.84 \\
\hline ICT use in the classroom & 6 & 0.70 & 3.61 & 0.55 & 0.72 & 3.62 & 0.60 \\
\hline $\begin{array}{l}\text { ICT as means to improve } \\
\text { skills and career }\end{array}$ & 2 & 0.68 & 3.77 & 0.67 & 0.68 & 3.60 & 0.86 \\
\hline ICT school access & 2 & 0.63 & 2.85 & 0.82 & 0.79 & 2.53 & 0.93 \\
\hline ICT use difficulties & 4 & 0.63 & 3.62 & 0.57 & 0.61 & 3.52 & 0.62 \\
\hline
\end{tabular}


displays the reliability coefficients for the six ICT-related variables under scrutiny, together with corresponding means and standard deviations for the whole sample in the pre-test and the posttest, respectively.

Since the Cronbach's alpha values of the questionnaires' scales are above 0.6, the instrument can be regarded as reliable (Dörnyei, 2007). As can be observed in Table 1, overall, all the ICT-related means resulted favorable (averages above 3.4), apart from the factor ICT school access, which referred to the quality and the quantity of the school's ICT equipment, and which was the only one with rather neutral to rather negative answers (means between 2.9 and 2.5 on a five-point scale).

No differences between the means in the pre-test and the post-test were found in the $t$-tests for all six ICT-related attitudinal variables but one, ICT school access, which experimented a statistically significant decrease in the means from the pre-test $(M=2.85, S D=0.82)$ to the post-test $[M=2.53, S D=0.93, t(61)=2.840, P=0.006]$. The calculation of eta squared value (0.12) indicated quite large effect size (Cohen, 1988). This may be due to the fact that the students were not very enthusiastic about the school's digital equipment (its quality and quantity) before the ICT-intervention, and resulted disenchanted with it after experiencing an actual use of it in their EFL classes.

When the sample was split by gender, the cross-sectional analysis performed confirmed no statistically significant differences between females and males in all ICT-related attitudinal variables at the two times of measurement, as displayed in Table 2 below.

Learners of both genders seem rather disappointed with the quality and the quantity of the school's ICT equipment -ICT school access variable- which, in fact, experienced a significant decrease among male students from the pre-test $(M=2.81, S D=0.80)$ to the post-test $[M=2.30, S D=0.85, t(22)=-4,128, P<0.001]$. The calculation of eta squared value $(0.44)$ indicated large effect size (Cohen, 1988). This result suggests that the disillusion of male students with the school's equipment after the ICT intervention was such, that it was the cause of the significant difference between the pre-test and the post-test means of ICT school access variable found for the whole group.

An interesting fact is that when the sample was split according to English grades obtained at the end of Secondary school into low achievers (those who obtained a passing grade of 5.0), medium (5.1-6.9) and high achievers (7-10), the cross-sectional analysis did not reveal any statistically significant differences between the three subgroups for ICT-related attitudinal variables neither in the pre-test, nor in the post-test. The mean scores are displayed in Table 3 below.

Table 2. Attitudes towards ICT. Mean scores for the sample split by gender

\begin{tabular}{|c|c|c|c|c|c|c|}
\hline \multirow[b]{3}{*}{ Variables } & \multicolumn{3}{|c|}{ Pre-test $(N=77)$} & \multicolumn{3}{|c|}{ Post-test $(N=62)$} \\
\hline & \multirow[b]{2}{*}{ Mean } & \multicolumn{2}{|c|}{ Gender } & \multirow[b]{2}{*}{ Mean } & \multicolumn{2}{|c|}{ Gender } \\
\hline & & Males & Females & & Males & Females \\
\hline ICT as support for learning & 3.62 & 3.60 & 3.63 & 3.65 & 3.83 & 3.56 \\
\hline ICT as means to improve English & 3.44 & 3.39 & 3.46 & 3.52 & 3.71 & 3.41 \\
\hline ICT use in the classroom & 3.61 & 3.47 & 3.69 & 3.63 & 3.70 & 3.59 \\
\hline $\begin{array}{l}\text { ICT as means to improve skills and } \\
\text { career }\end{array}$ & 3.77 & 3.84 & 3.72 & 3.62 & 3.80 & 3.51 \\
\hline ICT school access & 2.85 & 2.81 & 2.88 & 2.55 & 2.30 & 2.69 \\
\hline ICT use difficulties & 3.62 & 3.58 & 3.64 & 3.53 & 3.55 & 3.51 \\
\hline
\end{tabular}


Last but not least, we wished to explore any possible difference between the learners who were positive towards ICT from the start, and those who were not, as such a priori disposition may affect learners' interaction with technology in the classroom. The sample was divided according to the average scores of the questionnaire in the pre-test into two subgroups of learners, namely, ICT-neutral (those who displayed a mean score from 2.50 to 3.29) and ICT-favorable $(M=3.30-5.00)$. It is worth mentioning that only 5 students demonstrated an average score below 2.50 at the onset of the study, and they were included in the "ICT-neutral" subgroup. Hence, independent samples $t$-tests revealed statistically significant differences in the pre-test between the two subgroups of learners, for all ICT-related attitudinal variables: ICT as support for learning $[t(75)=-7.622, P<0.001]$; ICT as means to improve English $[t(75)=-6.826$, $P<0.001]$; ICT use in the classroom $[t(75)=-6.045, P<0.001]$; ICT as means to improve skills and career $[t(75)=-4.763, P<0.001]$; ICT school access $[t(75)=-2.917, P=0.005]$; and ICT use difficulties $[t(75)=-2.805, P=0.006]$. As can be observed in Table 4 below, the mean scores of ICT-positive students in the pre-test exceed significantly the ones of ICT-neutral students.

Nevertheless, no differences between ICT-neutral and ICT-favorable students were found in the post-test, with the latter showing a slight decrease in the mean scores, and the former displaying an increase trend in their mean scores for all the variables but one, which was related to the access to the ICT offered at school, referring to the quantity and the quality of the school's ICT equipment.

\section{Qualitative insights on ICT use in EFL classroom}

The questions which guided the interviews with the participants included their opinion on the experience with computers in English classes, whether they found it interesting and useful, what they liked most and least, and whether they experienced any difficulties. Among the positive ideas mentioned by the students, we can find the blog being a novelty (7 comments), since it was something they might not have known and now have learned to manage. Nevertheless, it seems at the same time the thing they disliked and had some difficulties with its use, especially as far as writing on the blogs is concerned ( 5 comments), as indicated by one of the students: "Me, for example, I didn't see the point, a blog (...) I saw it very difficult to write on the blog" (student 55).

Table 3. Attitudes towards ICT. Mean scores for the sample split by grades (type of achiever)

\begin{tabular}{|c|c|c|c|c|c|c|c|c|}
\hline \multirow[b]{3}{*}{ Variables } & \multicolumn{4}{|c|}{ Pre-test $(N=77)$} & \multicolumn{4}{|c|}{ Post-test $(N=62)$} \\
\hline & \multirow[b]{2}{*}{ Mean } & \multicolumn{3}{|c|}{ Type of achiever } & \multirow[b]{2}{*}{ Mean } & \multicolumn{3}{|c|}{ Type of achiever } \\
\hline & & Low & Medium & High & & Low & Medium & High \\
\hline ICT as support for learning & 3.62 & 3.75 & 3.59 & 3.58 & 3.65 & 3.68 & 3.51 & 3.70 \\
\hline $\begin{array}{l}\text { ICT as means to improve } \\
\text { English }\end{array}$ & 3.44 & 3.59 & 3.37 & 3.41 & 3.52 & 3.42 & 3.76 & 3.46 \\
\hline ICT use in the classroom & 3.61 & 3.86 & 3.45 & 3.58 & 3.63 & 3.61 & 3.62 & 3.65 \\
\hline $\begin{array}{l}\text { ICT as means to improve } \\
\text { skills and career }\end{array}$ & 3.77 & 3.62 & 3.97 & 3.73 & 3.62 & 3.53 & 3.82 & 3.57 \\
\hline ICT school access & 2.85 & 2.74 & 2.82 & 2.91 & 2.55 & 2.90 & 2.50 & 2.41 \\
\hline ICT use difficulties & 3.62 & 3.65 & 3.57 & 3.63 & 3.53 & 3.58 & 3.36 & 3.57 \\
\hline
\end{tabular}


It seems that they have enjoyed the Web-based information search, some useful websites visited during the class, and appreciated a different use of ICT during their sessions, and the guiding role of the teacher with the Internet search, as illustrated by the following quotations from a student's comment: "Not with X [ICT-intervention EFL teacher] but in other classes if we use the computer [the usual EFL teacher] shows how the grammar should be, like in a book, on a screen, so it's the same" (student 21); "But this is not always correct, because the Internet is not always reliable, but if you have a teacher to tell you: this is not like that, you need to search for it here, it's helpful" (student 48).

On the other hand, some students stated the ICT used were very basic and not new to them, and two said the project was not useful to improve their digital skills. It may be the case that they still see the use of ICT as just another tool to work on English and they would be happier only if they could choose what to work on. It seems that a key issue is that they need to be more autonomous and if the use of ICT is guided by the teacher, they do not enjoy it as much as if they could make their own decisions.

\section{DISCUSSION AND CONCLUSION}

Overall, attitudes towards ICT displayed by the participants of this study were positive, as technology was considered useful in order to support EFL learning (ICT as a support for learning), and helpful to improve language skills (ICT as means to improve English). The learners acknowledged the positive role of technology as means through which classroom activities are carried out, and EFL learning process and classes result more interesting (ICT use in the classroom). In addition, employing ICT in learning environment was considered rather helpful for developing general digital skills, and positive way to improve students' future career or employment perspectives (ICT as means to improve skills and career). However, the latter was not entirely supported by the qualitative data, as some critical voices regarding the classroom use of rather basic technology appeared in the interviews. In any case, despite learners' detracting opinion on the school's ICT equipment's accessibility and quality (ICT school access), any possible obstacles they may have encountered while carrying out ICT-based EFL activities (ICT use difficulties) did not affect participants' generally favorable disposition towards technology in their classes.

Table 4. Attitudes towards ICT. Mean scores for the sample split by initial attitude towards technology

\begin{tabular}{|c|c|c|c|c|c|c|}
\hline \multirow[b]{3}{*}{ Variables } & \multicolumn{3}{|c|}{ Pre-test $(N=77)$} & \multicolumn{3}{|c|}{ Post-test $(N=62)$} \\
\hline & \multirow[b]{2}{*}{ Mean } & \multicolumn{2}{|c|}{ Initial ICT attitude } & \multirow[b]{2}{*}{ Mean } & \multicolumn{2}{|c|}{ Initial ICT attitude } \\
\hline & & Neutral & Favorable & & Neutral & Favorable \\
\hline ICT as support for learning & 3.62 & 3.27 & 4.08 & 3.65 & 3.69 & 3.59 \\
\hline ICT as means to improve English & 3.44 & 3.07 & 3.93 & 3.52 & 3.44 & 3.61 \\
\hline ICT use in the classroom & 3.61 & 3.34 & 3.97 & 3.63 & 3.53 & 3.73 \\
\hline $\begin{array}{l}\text { ICT as means to improve skills and } \\
\text { career }\end{array}$ & 3.77 & 3.49 & 4.14 & 3.62 & 3.50 & 3.72 \\
\hline ICT school access & 2.85 & 2.63 & 3.15 & 2.55 & 2.45 & 2.62 \\
\hline ICT use difficulties & 3.62 & 3.47 & 3.82 & 3.53 & 3.58 & 3.45 \\
\hline
\end{tabular}


These findings corroborate the results of previous research in the field, as the learners appreciated the "hands-on" use of computers for classroom purposes (Doiz et al., 2014; Liu, 2009), and positively valued the experience of interacting with ICT (Czékmán, 2018; Ipiña 2012; Siragusa \& Dixon 2009). The "fun factor" attributed to using technology in EFL learning seem to engage the students in the learning process, and thus may improve their attitudes towards learning as such (Golonka et al., 2014; Stockwell, 2013), as opposed to the lack of enjoyment related to more "traditional" EFL teaching approaches.

However, the expected improvement in students' attitudes towards the educational employment of technology after experiencing the classroom use of ICT, suggested by Warschauer (1996), was not fully confirmed in the findings, as no significant increase in learners' attitudes towards ICT was found. In fact, in the case of ICT school access variable, male students' means experimented a significant decline from the pre-test to the post-test. This unexpected result may be accounted for by the rather neutral attitude becoming a gradual disillusionment of males with the school's digital equipment, which was not very cutting-edge, probably in comparison to the quality of technology they may have access to out of school. However, no other gender-related differences were found in this study.

It should also be highlighted that no difference in their ICT-related mindset was found between low, medium and high achievers at the two points of measurement, which suggests that they may hold similar expectations and feel equally benefitted by the classroom use of technology for EFL learning. Moreover, at the end of the intervention, there was no difference detected between those students who were initially ICT-neutral and those ICT-favorable. It is worth emphasizing that learners' general positive disposition regarding ICT use in EFL classes was (except for one variable) maintained after the 18-month technology-based intervention, beyond the possible "novelty effect", which supports the claims in favor of ICT's integration in EFL teaching. However, it has to be mentioned that more research is needed to determine the effectiveness of ICT-mediated activities or the motivational potential attributed to them on students' actual FL learning outcomes. On the whole, more widespread and systematic integration of learners' "hands-on" experience with ICT in the mainstream EFL teaching is required, including a wider array of software, devices, and technology-based task types.ICT'

Ethics: The study procedures were carried out in accordance with the Declaration of Helsinki. After the school principal's approval of the project, consent forms signed by the participants' parents were gathered before the onset of the study. No student expressed their disconformity throughout the project. The data obtained were anonymized, kept confidential, and stored accordingly.

Funding sources: This research was supported by the following grants: FFI2012-34214 (Spanish Ministry of Economy and Competitiveness), IT311-10 (Department of Education, University and Research of the Basque Government), and ZABALDUZ (Vice-rector of Investigation of the University of the Basque Country).

Author's contribution: The author had full access to all data in the study and takes responsibility for the integrity of the data and the accuracy of the data analysis.

Conflict of interest: The author declares no conflict of interest. 


\section{ACKNOWLEDGMENTS}

I would like to express my gratitude to the school management, the staff and the students for participating in the study.

\section{APPENDIX}

\section{Questionnaire}

Please, indicate on a scale from 1 to 5 to what extent you agree or disagree with the following statements:

\section{Totally disagree}

1
Disagree

2

\section{Neither agree nor disagree \\ 3}

Agree

4
Totally agree

5

Example: If you totally agree with this statement, indicate it in the following manner:

I like skiing.

1234 (5)

12345

12345

12345

12345

12345

12345

12345

12345

12345

12345

12345

12345

12345

12345

12345

12345

12345

12345

12345

12345

12345

12345 


\section{ABOUT THE AUTHOR}

Marta Kopinska graduated in Ethnolinguistics from Adam Mickiewicz University of Poznan (AMU, Poland). She received her PhD in English Studies (Applied Linguistics) within the program Language Acquisition in Multilingual Settings at the University of the Basque Country (UPV/EHU, Spain), where she is currently a lecturer in the Department of English and German Studies and Translation and Interpreting. She is a member of the Language and Speech group (LasLab) and her main research interests include EFL and L2/L3 acquisition, ICT in EFL teaching and learning, young EFL learners (YLs), multilingual education, and language attitudes and motivation.

\section{REFERENCES}

BOE. (2015, January 19). Orden ECD/65/2015, de 21 de enero, por la que se describen las relaciones entre las competencias, los contenidos y los criterios de evaluación de la educación primaria, la educación secundaria obligatoria y el bachillerato, Vol. 25. (pp. 6986-7003). Boletín Oficial de Estado. Retrieved from https://www.boe.es/diario_boe/txt.php?id=BOE-A-2015-738.

Cohen, J. (1988). Statistical power analysis for the behavioral sciences (2nd ed.). Hillsdale, NJ: Erlbaum.

Czékmán, B. (2018). Tablet supported education in a Hungarian primary school: Results of students and teachers. Hungarian Educational Research Journal, 8(2), 127-130. doi:10.14413/HERJ/8/2/11.

De Moya, M. V., Hernández, J. R., Hernández, J. A., \& Cózar, R. (2011). Análisis de los estilos de aprendizaje y las TIC en la formación personal del alumnado universitario a través del cuestionario REATIC. Revista de Investigación Educativa, 29(1), 137-156.

Delgado, A. J., Wardlow, L., McKnight, K., \& O’Malley, K. (2015). Educational technology: A review of the integration, resources, and effectiveness of technology in K-12 classrooms. Journal of Information Technology Education: Research, 14, 397-416.

Doiz, A., Lasagabaster, D., \& Sierra, J. M. (2014). Giving voice to the students what (de)motivates them in CLIL classes?. In D. Lasagabaster, A. Doiz, \& J. M. Sierra (Eds.), Motivation and foreign language learning. From theory to practice (pp. 117-138). Amsterdam/Philadelphia: John Benjamins Publishing Company.

Dörnyei, Z. (2007). Research methods in applied linguistics: Quantitative, qualitative, and mixed methodologies. Oxford: Oxford University Press.

EHAA. (2016a, January 15). 236/2015 DEKRETUA, abenduaren 22koa, Oinarrizko Hezkuntzaren curriculuma zehaztu eta Euskal Autonomia Erkidegoan ezartzen duena. Hezkuntza, Hizkuntza Politika eta Kultura Saila. Euskal Herriko Agintaritzaren Aldizkaria, 9. Retrieved from https:/www.euskadi.eus/ y22-bopv/es/bopv2/datos/2016/01/1600141e.pdf.

EHAA. (2016b, September 23). 127/2016 DEKRETUA, irailaren 6koa, Batxilergoko curriculuma zehaztu eta Euskal Autonomia Erkidegoan ezartzekoa. Hezkuntza, Hizkuntza Politika eta Kultura Saila. Euskal Herriko Agintaritzaren Aldizkaria, 182. Retrieved from http://www.hezkuntza.ejgv.euskadi.eus/ contenidos/informacion/heziberri_2020/eu_2_proyec/adjuntos/Dekretua_127_2016_batx_e.pdf.

Eskola 2.0 project. Presentación del programa Eskola 2.0 del Gobierno Vasco. Retrieved from http://www. eskola20.euskadi.net/web/guest/introduccion.

European Commission. (2012). Survey of schools: ICT in education. Country profile. Spain: European Schoolnet and University of Liège. Retrieved from https://ec.europa.eu/digital-single-market/sites/ digital-agenda/files/Spain\%20country\%20profile.pdf. 
European Commission. (2013). Survey of schools: ICT in education. Benchmarking access, use and attitudes to technology in Europe's schools. European Schoolnet and University of Liège. Retrieved from https:// ec.europa.eu/digital-agenda/en/survey-schools-ict-education.

European Parliament. (2006). Key competences for lifelong learning. Recommendation 2006/962/EC of the European parliament and of the council of 18 December 2006 on key competences for lifelong learning. Retrieved from http://eur-lex.europa.eu/legal-content/EN/TXT/PDF/?uri=CELEX:32006H0962\&rid=3.

Eurydice (2012). Key data on teaching languages at school in Europe 2012. Brussels: European commission. Retrieved from http://eacea.ec.europa.eu/education/eurydice/documents/key_data_series/143en.pdf.

Ferrari, A. (2013). DIGCOMP: A framework for developing and understanding digital competence in Europe. Luxembourg: Publications Office of the European Union.

Fitzpatrick, A. (2004). Information and communication technology in foreign language teaching and learning - An Overview. In UNESCO, Information and communication Technologies in the Teaching and Learning of foreign languages: State-of-the-art, Needs and perspectives (pp. 10-26). Moscow: UNESCO Institute for Information Technologies in Education.

Golonka, E. M., Bowles, A. R., Frank, V. M., Richardson, D. L., \& Freynik, S. (2014). Technologies for foreign language learning: A review of technology types and their effectiveness. Computer Assisted Language Learning, 27(1), 70-105.

Gray, K., Kennedy, G., Waycott, J., Dalgarno, B., Bennett, S., Chang, R., et al. (2009). Educating the net generation. A toolkit of resources for Educators in Australian universities. Australian Learning and Teaching Council Ltd.

Guo, Z., \& Stevens, K. J. (2011). Factors influencing perceived usefulness of wikis for group collaborative learning by first year students. Australasian Journal of Educational Technology, 27(2), 221-242.

Henry, A., Sundquist, P., \& Thorsen, C. (2019). Motivational practice: Insights from the classroom. Lund, Sweden: Studentlitteratur.

Hernández, J. A., Hernández, J. R., De Moya, M., García, F. J., \& Bravo, R. (2010). Estilos de aprendizaje y TIC en la formación del alumno universitario de Magisterio. Girona, Spain: Paper presented at II Congrés Internacional de Didàctiques, CiDd. (February 3-6, 2010).

Hew, K. F., \& Cheung, W. S. (2013). Use of Web 2.0 technologies in K-12 and higher education: The search for evidence-based practice. Educational Research Review, 9, 47-64.

Hockly, N. (2013). Mobile learning. English Language Teaching Journal, 67(1), 80-84.

Ipiña, N. (2012). The use of wikis in a CLIL-POL context as tools for collaborative writing. Impact of attitudes. PhD thesis, Mondragon University.

Kopinska, M. (2016). Motivational drive of a technology-based 'weak' version of CLIL. In D. Lasagabaster, \& A. Doiz (Eds.), CLIL experiences in secondary and tertiary education: In search of good practices (pp. 99-124). Bern: Peter Lang.

Lasagabaster, D., \& Sierra, J. M. (2003). Students' evaluation of CALL software programs. Educational Media International, 40(3-4), 293-304.

Levy, M. (2009). Technologies in use for second language learning. Modern Language Journal, 93, 769-782.

Li, J., Snow, C., Jiang, J., \& Edwards, N. (2015). Technology use and self-perceptions of English language skills among urban adolescents. Computer Assisted Language Learning, 28(5), 450-478.

Liu, J. (2009). A survey of EFL learners' attitudes toward information and communication technologies. English Language Teaching, 2(4), 101-106.

Margaryan, A., Littlejohn, A., \& Vojt, G. (2011). Are digital natives a myth or reality? University students' use of digital technologies. Computers and Education, 56(2), 429-440. 
Martínez-Rico, P. M. (2006). La presencia de las Tecnologías de Información y Comunicación en el aula de inglés de secundaria: Descripción del marco contextual y análisis de la motivación de los alumnos. ( $\mathrm{PhD}$ thesis). University of Barcelona.

Prensky, M. (2001). Digital natives, digital immigrants. On the Horizon, 9(5), 1-6.

Puentedura, R. (2010). SAMR and TPCK: Intro to advanced practice. Retrieved from http://hippasus.com/ resources/sweden2010/SAMR_TPCK_IntroToAdvancedPractice.pdf.

Schmelzer, R., Gessler, M., Kanova, I., Pokorný, I.M., Kovacs, Z., \& Kohlrusz, G. et al. (2016). Pedagogy of multinational realtime online trainings (webinars) for blended learnings. Hungarian Educational Research Journal, 6(3), 107-123. doi:10.14413/HERJ.2016.03.11.

Siragusa, L., \& Dixon, K. C. (2009). Theory of Planned Behaviour: Higher education students' attitudes towards ICT-based learning interaction. Retrieved from: https://pdfs.semanticscholar.org/cd12/ 714a56590f68abfadde93ea3396cc7667542.pdf. Proceedings ASCILITE Auckland, Australia, 969-980.

Stockwell, G. (2013). Technology and motivation in English-language teaching and learning. In E. Ushioda (Ed.), International perspectives on motivation: Language learning and professional challenges (pp. 156175). Basingstoke: Palgrave Macmillan.

Ushioda, E. (2011). Language learning motivation, self and identity: Current theoretical perspectives. Computer Assisted Language Learning. 24(3), 199-210.

Warschauer, M. (1996). Motivational aspects of using computers for writing and communication. In M. Warschauer (Ed.), Telecollaboration in foreign language learning (pp. 29-46). Honolulu, HI: University of Hawai'i Second Language Teaching and Curriculum Center.

Williams, M., Burden, R., \& Lanvers, U. (2002). 'French is the language of love and stuff: Student perceptions of issues related to motivation in learning a foreign language. British Educational Research Journal, 28, 503-528.

Open Access statement. This is an open-access article distributed under the terms of the Creative Commons AttributionNonCommercial 4.0 International License (https://creativecommons.org/licenses/by-nc/4.0/), which permits unrestricted use, distribution, and reproduction in any medium for non-commercial purposes, provided the original author and source are credited, a link to the CC License is provided, and changes - if any - are indicated. 